\title{
Growth of the mussel Mytilus edulis L. in the Wadden Sea affected by tidal emergence and barnacle epibionts
}

\author{
Christian Buschbaum*, Bettina Saier* \\ Alfred-Wegener-Institut für Polar- und Meeresforschung, Wadden Sea Station Sylt, Hafenstraße 43, D-25992 List, Germany
}

Received 6 June 2000; accepted 1 November 2000

\begin{abstract}
On the tidal flats in the Wadden Sea mussels Mytilus edulis form extensive epibenthic beds. Near the island of Sylt (German Bight, North Sea), these extend from mid intertidal to shallow subtidal zones and are often heavily overgrown by barnacles (Semibalanus balanoides and Balanus crenatus). The effects of tidal emergence and barnacle epibionts on growth in M. edulis were investigated by field experiments and surveys. The results showed that mussel cohort lengths increased from the mid intertidal ( $25-35 \mathrm{~mm}$ shell length) over low intertidal $(30-45 \mathrm{~mm})$ to the subtidal zone $(45-60 \mathrm{~mm})$. In the low intertidal zone M. edulis were heavily overgrown by barnacles $\left(2.2 \pm 0.4 \mathrm{~g}\right.$ dry weight mussel $\left.^{-1}\right)$, while balanid epigrowth was significantly lower subtidally $\left(0.9 \pm 0.4 \mathrm{~g} \mathrm{mussel}^{-1}\right)$ as well as in the mid intertidal zone $\left(0.7 \pm 0.3 \mathrm{~g} \mathrm{mussel}^{-1}\right)$. Cross-transplantation experiments of clean mussels (25-35 mm length) showed that from July to September growth was about $3 \mathrm{~mm}$ in the intertidal zone and significantly increased to about $10 \mathrm{~mm}$ subtidally. Mussel origin had no influence upon growth. Further field experiments showed significantly lower growth in mussels with barnacles than without. Living and experimentally sealed barnacles did not differ in their effect, indicating that food competition was not responsible. This investigation suggests that fluctuations in the extent of barnacle epigrowth may modify growth patterns in M. edulis which are otherwise governed by tidal exposure. (C) 2001 Elsevier Science B.V. All rights reserved.
\end{abstract}

Keywords: Mytilus edulis; Barnacles; Growth; Intertidal; Subtidal; Epibiosis

\section{Introduction}

Growth of benthic suspension feeders such as Mytilus edulis L. is influenced by water temperature, salinity, current velocity and wave impact as well as food quality and quantity (e.g. Coulthard, 1929; Harger, 1970; Kennedy, 1976; Bayne and Worrall, 1980; Incze et al., 1980; Kautsky, 1982; Fréchette and Bourget, 1985a; Wildish and Kristmanson,

\footnotetext{
* Corresponding authors.

E-mail addresses: cbuschbaum@awi-bremerhaven.de

(C. Buschbaum),

bsaier@awi-bremerhaven.de (B. Saier).
}

1985; Seed and Suchanek, 1992). Mussel size and age are also important (Baird, 1966; Seed, 1968; Widdows et al., 1984) and at high mussel densities intraspecific competition for food may reduce growth rate in bivalves (Bertness and Grosholz, 1985; Wildish and Kristmanson, 1985; Okamura, 1986; Newell, 1990). On tidal coasts, duration of air exposure is considered to be one of the most important factors for growth in mussels (Baird and Drinnan, 1957; Baird, 1966; Bertness and Grosholz, 1985; Faldborg et al., 1994; McGrorty et al., 1993; McGrorty, 1997) and may lead to considerable variations in size and shape between intertidal and subtidal $M$. edulis (Baird, 1966; Seed, 1968). Epibionts have also been 


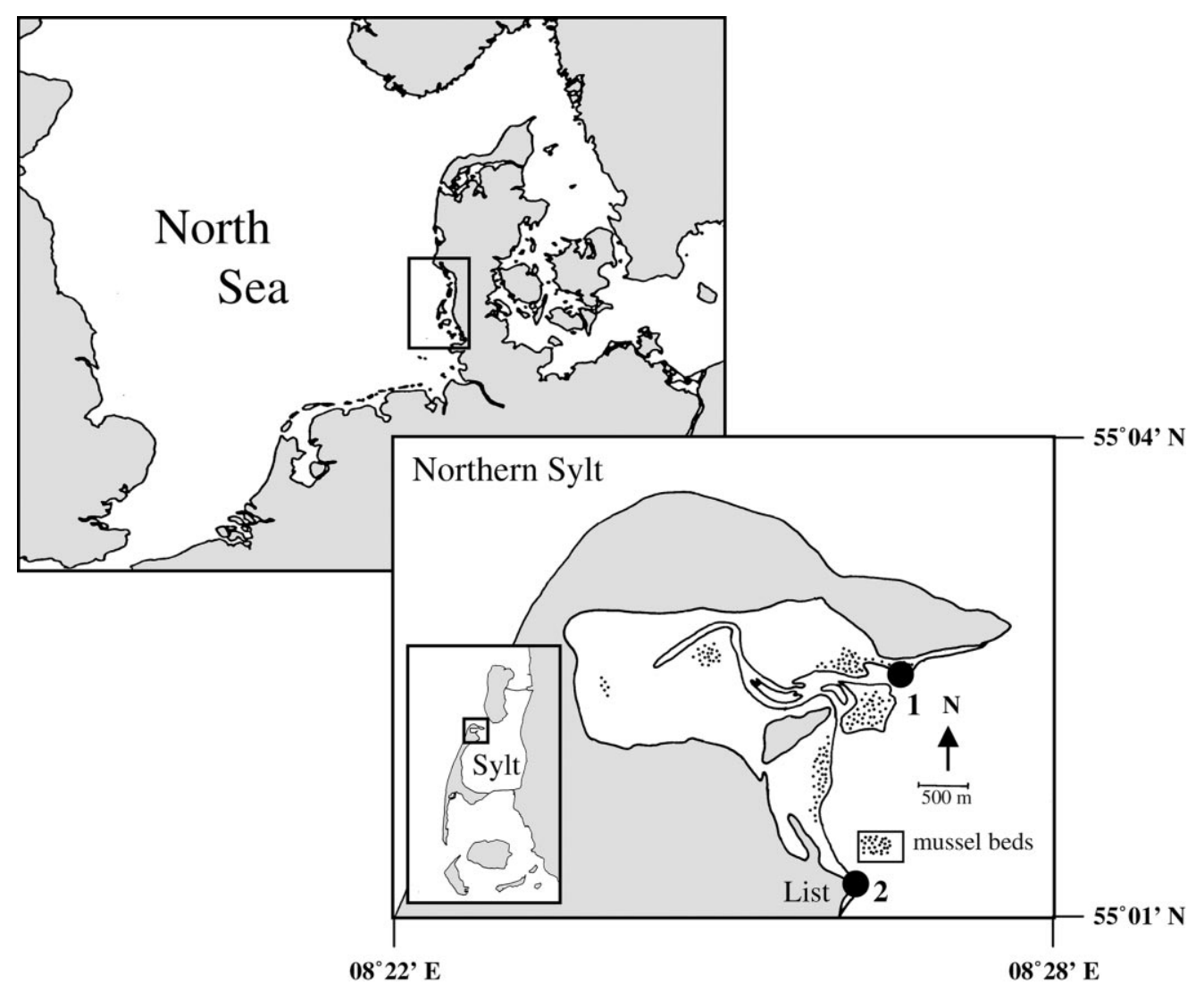

Fig. 1. Tidal flats of Königshafen with mussel beds (dotted). All experiments were carried out at a mussel bed located at the mouth of a tidal channel $(\bullet 1)$. Mussels for experiments were collected near List harbour

shown to influence mussel growth. Dittmann and Robles (1991), for example, observed decreasing length increment in mussels overgrown by algae, whilst experimental removal of epiphytes led to increasing growth rates. For a comprehensive understanding of size distributions in mussel beds, the analysis of interactions between major factors is important and was pursued in this study on growth of M. edulis in the Wadden Sea. On tidal flats near the island of Sylt, mussel beds extend from intertidal to adjacent subtidal zones within a few metres of horizontal distance and, therefore, present an excellent study site to compare and quantify the effects of tidal submergence on growth in M. edulis. Moreover, these mussel beds are commonly overgrown by barnacles (Albrecht, 1998; Buschbaum, 2000) among which Semibalanus balanoides L. dominates the intertidal zone while Balanus crenatus Bruguière is primarily found at subtidal sites (Albrecht and Reise, 1994; Buhs and Reise, 1997). During the investigation period of 1998 balanid cover was high; however, barnacle abundance and distribution may often show highly variable interannual fluctuations (Southward, 1991; Bertness et al., 1992; Miron et al., 1995; Buschbaum, 2000) which presumably affect growth patterns in $M$. edulis in addition to tidal emergence.

This study tested whether mussel growth rates increased with submergence time by cross-transplanting mussels to intertidal and adjacent subtidal sites. We furthermore hypothesised that mussels with barnacle epibionts suffer from food competition since both species are filter feeders with overlapping spectra of food particle size down to $2 \mu \mathrm{m}$ (Barnes, 1959; Møhlenberg and Riisgard, 1977). Thus, we expected reduced growth rates in fouled M. edulis. Subsequently, we checked for interacting effects and 


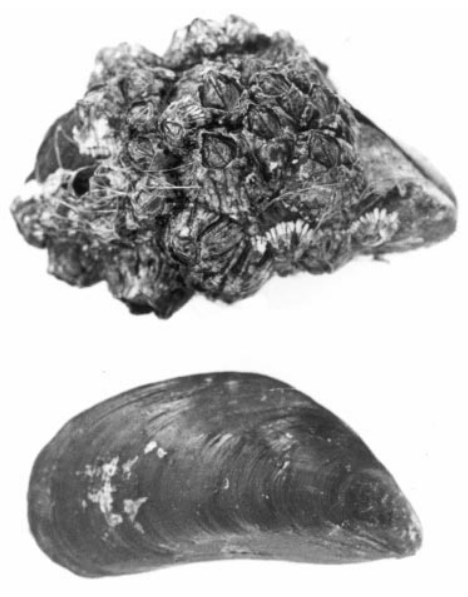

Fig. 2. Barnacle-overgrown (above), and clean M. edulis (below).

quantified the relative contributions of the two factors: tidal submergence and barnacle epigrowth. In surveys we compared size structures of mussel beds from different tidal levels and concurrently measured their overgrowth with $S$. balanoides and B. crenatus. Size differences between mussel cohorts were assumed to increase with increasing time of submergence whilst barnacle epigrowth was expected to modify growth patterns of M. edulis in the Wadden Sea.

\section{Material and methods}

\subsection{Study area}

Field surveys were performed at mussel beds located in Königshafen, a sheltered tidal bay at the northern tip of the island of Sylt (North Sea, German Bight; $55^{\circ} 02^{\circ} \mathrm{N}, 08^{\circ} 26^{\circ} \mathrm{E}$ ) (Fig. 1). That area is protected from harsh westerly wind conditions by a sand dune system. Tidal waters enter the bay through a tidal channel in an east-west direction. Tides are semidiurnal and average tidal range is about $1.8 \mathrm{~m}$. Average salinity is $30 \mathrm{psu}$ and mean water temperature is $15^{\circ} \mathrm{C}$ in summer and $4^{\circ} \mathrm{C}$ in winter. A detailed description of the hydrography, geology, sediments and biota of the study area is given by Reise (1985), G. Austen (1994), I. Austen (1994), Bayerl and Higelke (1994) and Reise et al. (1994). Mussel beds comprise about
$1 \%$ of the intertidal area of Königshafen (Reise et al., 1994). The investigated beds of M. edulis are all located close to the low water tide mark and therefore represent both intertidal and subtidal areas within a few metres of horizontal distance. Mean exposure time of the low intertidal and mid intertidal mussel beds was between 1 and $3 \mathrm{~h}$ per tide, respectively. In this investigation subtidal habitats are referred to as areas remaining submerged at spring water low tides and comprise water depths of about $0.5-1 \mathrm{~m}$ at low tide.

\subsection{Length frequency distribution of M. edulis}

To obtain length distributions of M. edulis in intertidal and subtidal zones, samples were collected in the mid intertidal, low intertidal and in the subtidal zones using a stratified random sampling design. A total of 18 samples per tidal level were investigated. Sampling was carried out in September 1998, using a box corer of $500 \mathrm{~cm}^{2}$. The contents were washed through $1-\mathrm{mm}$ meshes to collect all mussels except the smallest recruits. Mussels were counted and their length measured (maximum anterior-posterior axis) to the nearest $0.1 \mathrm{~mm}$ using vernier callipers and then grouped into 5-mm size classes.

\subsection{Barnacle overgrowth}

We quantified barnacle overgrowth at the same investigation sites as for length frequency distribution of $M$. edulis. Six replicate samples were taken in September 1998, using a box corer of $315 \mathrm{~cm}^{2}$ in mid intertidal, low intertidal as well as subtidally. Barnacle species composition of each mussel was recorded and barnacle coverage of each mussel shell surface was estimated to the nearest $25 \%$. Then, barnacles attached to mussel shell surfaces were scratched off and dried at $75^{\circ} \mathrm{C}$ for 3 days. Mussels per sample were counted and dry weight of balanids was determined to the nearest $0.01 \mathrm{~g}$. Mean barnacle dry weight per mussel was calculated for each sample. Only M. edulis of $>35 \mathrm{~mm}$ shell length were considered because balanids generally occurred from this size upward. This may be due to the ability of small M. edulis to clean their shells with their foot (Theisen, 1972). 


\subsection{Mussel growth experiments}

Experiments on mussel growth were performed in the summer of 1998 and 1999 at location 1 (Fig. 1). Clean and barnacle overgrown $M$. edulis were collected near List harbour where they occurred from the intertidal to the subtidal zone on an artificial hard substrate (boat slipway). At this site, small (25-35-mm-long) mussels were exceptional in being heavily overgrown with barnacles. This size class was used because length increments of larger specimens were expected to be too small to clearly demonstrate effects of tidal submergence and barnacle epibionts.

To test whether mussel origin and tidal level might affect growth in M. edulis, naturally clean mussels of intertidal and subtidal origin were transplanted to both low intertidal (mean exposure time $1 \mathrm{~h}$ ) and subtidal (water depth of about $0.5 \mathrm{~m}$ at low tide) zones of a mussel bed.

To determine whether barnacle epibionts affect growth and how tidal level and epigrowth interact, intertidal mussels covered with barnacles (shell coverage $\geq 50 \%$; Fig. 2) were also exposed in low intertidal and subtidal areas of the mussel bed. For each of the treatments, 60 replicates were exposed in pockets (one mussel per pocket) made of pvc-netting $(10 \times 20 \mathrm{~cm}$; mesh size of $10 \mathrm{~mm}$ ) on 2 July 1998 . These were fixed with iron rods and resampled after 12 weeks. To prevent effects of intraspecific competition for food, the experimental set-ups of both tidal zones were fixed at the edge of a tidal channel with a strong current (about $0.5 \mathrm{~m} \mathrm{~s}^{-1}$ at moderate wind conditions, Behrens et al. 1996) which may determine food availability for suspension feeders (Fréchette and Bourget, 1985a). In addition, subtidal mussels were fixed just below the intertidal mussels in close horizontal distance of about $15 \mathrm{~m}$. Eventually, the pockets were fixed onto the top mussel layer to prevent food limitation due to a stagnant boundary layer (Fréchette and Bourget, 1985b). Individual lengths were recorded at the beginning and at the end of the experiment to the nearest $0.1 \mathrm{~mm}$ and length increment was calculated.

In the summer of 1999 an experiment was conducted to test whether the barnacle epibionts were responsible for a decreased growth in overgrown M. edulis. Again, mussels were taken from near List harbour. This experiment compared growth of (1) mussels collected with shells free of barnacles and (2) mussels with $\geq 50 \%$ coverage but cleaned from their barnacle epigrowth. A second experiment tested for food competition between $M$. edulis and their barnacle overgrowth. We used (1) mussels with natural barnacle epigrowth of at least $50 \%$ coverage and (2) mussels with barnacle valves sealed with seawater-resistant wax, which prevented balanid feeding activity but kept barnacle cones in place. Both experiments were performed on the low intertidal part of the mussel bed on 15 July 1999 and lasted for 12 weeks as described above. The number of replicates for each treatment was 32. The length of each mussel was recorded at the beginning and at the end of the experiments (see above).

\subsection{Statistical analysis}

Results are presented as arithmetic means with standard deviation $(\bar{x} \pm \mathrm{SD})$. Mussel growth increments were calculated as final mussel shell length minus initial mussel shell length. We did not correct growth rates for initial size differences (Kaufmann, 1981) because all tested growth models (Bertalanffy, Gompertz, power) showed a poor fit. In addition, all mussels used for growth experiments were within the same initial size range and showed no statistical size differences. Growth experiments were subjected to analysis of variance (ANOVA). Different levels within a significant experimental factor were analysed using Tukey's Honest-Significant-Difference (HSD) multiple comparison test. The relative magnitude of fixed factors was calculated according to Howell (1997). We applied the following formula:

$\omega^{2}=\left(\mathrm{SS}_{\text {treatment }}-[k-1] \mathrm{MS}_{\text {error }}\right) /\left(\mathrm{SS}_{\text {total }}+\mathrm{MS}_{\text {error }}\right) ;$

$\mathrm{k}=$ number of treatments, $\mathrm{SS}=\mathrm{sum}$ of squares, $\mathrm{MS}=$ mean squares

Cochran's test was used to test for homoscedasticity of variances and data of dependent variables were transformed $(\log (x+1))$ when variances were heterogeneous. In two cases (mussel growth rate comparisons between intertidal and subtidal; effects of barnacle epibionts on mussel growth in the intertidal and the subtidal) variances remained heterogeneous despite transformation. Those data were tested 


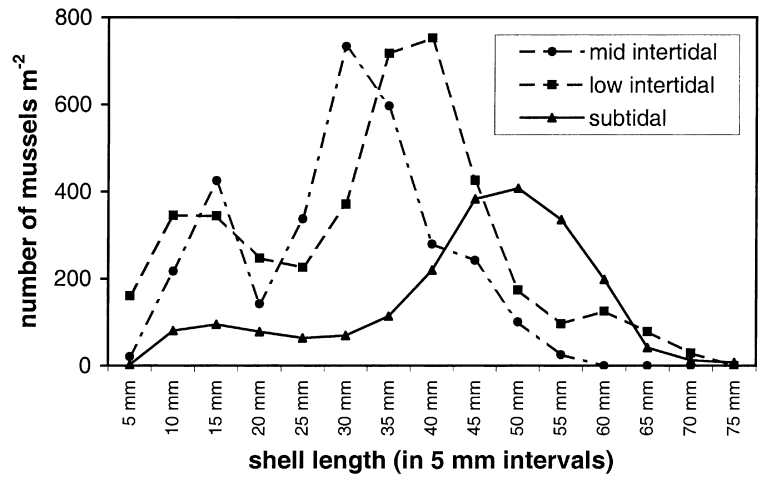

Fig. 3. Length frequency distribution of M. edulis at mid and low intertidal and shallow subtidal beds. Peaks of maximum numbers refer to strong mussel recruitment in 1996. Subtidal mussel beds showed a higher proportion of larger mussels but density was higher in the intertidal zone (each point represents the mean of 18 replicates).

for normality using the Kolmogorov-Smirnoff test. In both cases transformed data were normally distributed. Additionally, differences in mean values were much higher than differences in variances indicating that the influence of differences in variances on differences in mean values was negligible (Hennig, pers. comm., 2000). Therefore, ANOVA was applied in these two experiments despite heterogeneity of variances. Effects were considered to be statistically significant if the $P$-value was $<0.05$ and the Bonferroni-procedure was applied at multiple comparisons of data. Mortality rates in growth experiments were analysed by chi-square tests $(2 \times 2$ frequency tables $)$.

\section{Results}

\subsection{Length frequency distribution of M. edulis in intertidal and subtidal beds}

Mussel size structure and density differed between intertidal and subtidal sites (Fig. 3). In the subtidal, most individuals ranged from 45 to $60 \mathrm{~mm}$ (1996 cohort) in length. A minor peak occurred between 10 and $15 \mathrm{~mm}$ (1997 cohort). In the mid and low intertidal, the size-frequency distribution was distinctly bimodal. In the mid intertidal, maximum numbers were $10-15 \mathrm{~mm}$ (1997 cohort) and 25-35 mm (1996 cohort) and mussel length did not exceed $60 \mathrm{~mm}$. In the low intertidal, peaks were at 10-15 mm (1997 cohort) and 30-45 mm (1996 cohort), while mussels achieved about the same maximum length as subtidal specimens. Mussel size classes that were dominant at subtidal sites $(45-60 \mathrm{~mm})$ were under-represented at both intertidal sites. Density of $M$. edulis was two times higher in the intertidal $\left(4156 \pm 642 \mathrm{~m}^{-2}\right.$ in the mid intertidal and $4089 \pm 1257 \mathrm{~m}^{-2}$ in the low intertidal) than in the subtidal $\left(2104 \pm 1130 \mathrm{~m}^{-2}\right.$ ) (one-way ANOVA, $F=15.866, \mathrm{df}=2, P<0.0001$; followed by Tukey's test, $P<0.01)$. Mussel density did not significantly differ between mid and low intertidal sites (Tukey's test, $P=0.992$ ).

\subsection{Extent of barnacle overgrowth}

In the low intertidal dry weight of barnacle overgrowth per mussel $(2.18 \pm 0.40 \mathrm{~g})$ was significantly higher than in both the mid intertidal $(0.72 \pm 0.30 \mathrm{~g}$ mussel $\left.^{-1}\right)$ and the subtidal zone $(0.90 \pm 0.36 \mathrm{~g}$ mussel $^{-1}$ ) (one-way ANOVA, $F=30.280, \mathrm{df}=2$, $P<0.0001$; followed by Tukey's test, $P<0.001$ ) (Fig. 4). The extent of barnacle epigrowth was not significantly different in the higher intertidal and the subtidal zones (Tukey's test, $P=0.667$ ).

Correspondingly, barnacle percentage cover was strongest in low intertidal zones where $58 \%$ of the mussels had no or few barnacles, $29 \%$ were covered half, $8 \%$ reached up to three-quarters cover and $5 \%$ of mussel shells were totally covered. In mussels of the shallow subtidal and high intertidal zones, $82 \%$ had

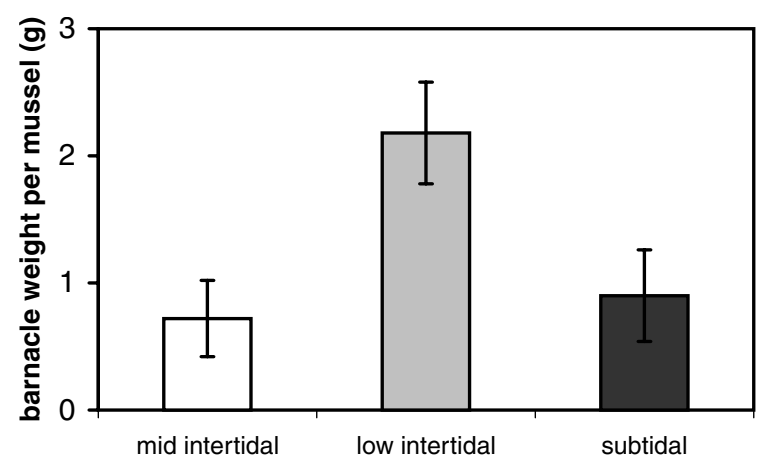

Fig. 4. Barnacle dry weight per mussel of intertidal and subtidal mussel beds (means of six replicates $\pm \mathrm{SD}$ ). Overgrowth of barnacles was highest on mussels in the low intertidal zone. 


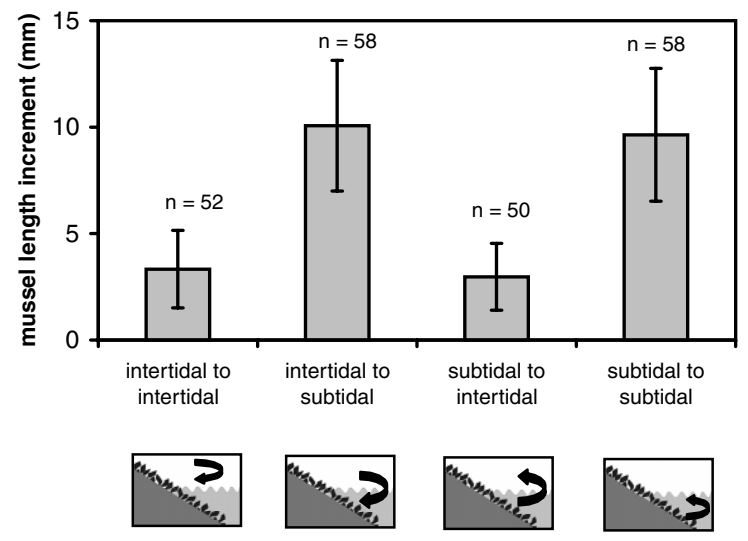

Fig. 5. Growth of M. edulis (initial length of $25-35 \mathrm{~mm}$ ) in the intertidal and subtidal zones (cross-transplantation of $4 \times 60$ mussels) (means of $n$ replicates $\pm \mathrm{SD} ; n=$ number of mussels alive at the end of the experiment) from July to September 1998. Mussel length increment in the intertidal was significantly lower compared to transplants to the subtidal. Mussel origin had no significant influence on growth.

no or little barnacle overgrowth, $12 \%$ were half covered or more, and no mussels were totally covered.

Barnacle species composition showed a tidal zonation. In the mid intertidal zone only $S$. balanoides occurred whilst in the subtidal zone $B$. crenatus was almost exclusively found on M. edulis. In low intertidal sites $S$. balanoides was dominant and present on all barnacle-overgrown mussels, whereas $B$. crenatus was found on $10 \%$ of mussels with barnacles. All balanids had a shell diameter of $\geq 5 \mathrm{~mm}$ and were $>4$ months old. They originated from barnacle recruitment in the spring of 1998 and previous years (pers. obs.).

\subsection{Mussel growth experiments}

\subsubsection{Effects of tidal level and mussel origin}

Tidal level significantly affected mussel growth rate (two-way ANOVA, $\quad F=364.331, \quad \mathrm{df}=1$, $P<0.0001$ ) (Fig. 5). Over the 12-week study period, intertidal $M$. edulis placed intertidally grew $3.3 \pm 1.8 \mathrm{~mm}$. Length increment was significantly lower than in intertidal mussels placed subtidally $(10.1 \pm 3.1 \mathrm{~mm})$. Mussel origin had no significant effect on mussel growth (two-way ANOVA, $F=0.973, \mathrm{df}=1, P=0.325)$. Growth of intertidal mussels placed intertidally did not significantly differ

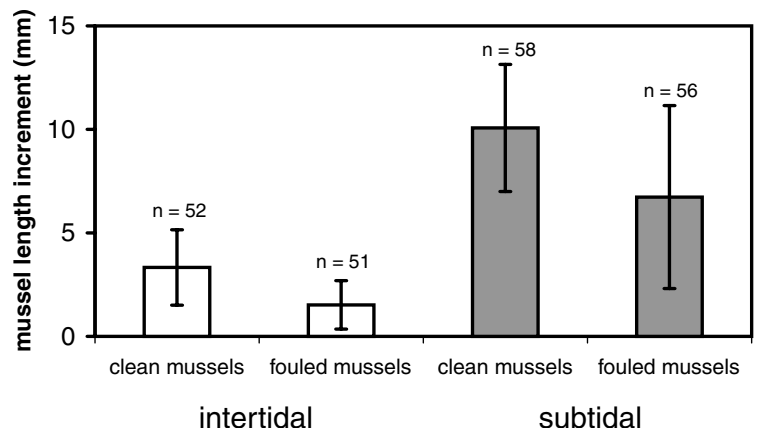

Fig. 6. Effects of barnacle epibionts on growth of M. edulis. Balanids significantly reduced mussel length increment in both intertidal and subtidal zones (means of $n$ replicates $\pm \mathrm{SD} ; n=$ number of mussels alive at the end of the experiments).

from that of subtidal transplants to the intertidal $(3.0 \pm 1.6 \mathrm{~mm})$. Neither was growth of subtidal mussels in the subtidal $(9.6 \pm 3.1 \mathrm{~mm})$ significantly different from that of intertidal transplants to the subtidal zone (see above). There were no significant interactions between location and origin (two-way ANOVA, $F=0.019$, df $=1, P=0.891$ ). Mortality was significantly higher intertidally (chi-square, $P<0.01$; data of intertidal and subtidal origin pooled) whilst mussel origin had no influence on mortality (chi-square, $P=0.655$; data of intertidal and subtidal location pooled).

\subsubsection{Effects of barnacle epibionts}

In 1998, barnacle epibionts significantly decreased growth in $M$. edulis (two-way ANOVA, $F=56.365$, $\mathrm{df}=1, P<0.0001$ ) (Fig. 6). In the intertidal zone clean mussels (see above, data from previous experiment) grew twice as much as fouled specimens (3.3 \pm 1.8 and $1.5 \pm 1.2 \mathrm{~mm}$, respectively). Subtidally, clean mussels attained a length increment of $10.1 \pm 3.1 \mathrm{~mm}$ (see above) compared to $6.7 \pm 4.4 \mathrm{~mm}$ in barnacle-covered conspecifics. As in previous experiments, tidal level significantly influenced mussel growth (two-way ANOVA, $F=194.438$, df $=1, P<0.0001)$. There were no significant interactions between barnacle overgrowth and tidal level on mussel growth rate (two-way ANOVA, $F=0.006, \mathrm{df}=1, \quad P=0.938$ ). Again, mortality was higher in the intertidal. No significant differences in mortality rate between clean and fouled 
mussels were detectable (chi-square, $P=0.512$; data of intertidal and subtidal location pooled).

The analysis of the relative magnitude of the two major factors affecting mussel growth revealed that tidal level $\left(\omega^{2}=0.42\right)$ was 3.5 times higher than barnacle epibionts $\left(\omega^{2}=0.12\right)$ in the experiments in 1998.

In 1999, growth increment of mussels in which balanids were removed by hand $(4.3 \pm 1.8 \mathrm{~mm})$ was not significantly different from mussels with naturally clean shell surfaces $(5.0 \pm 2.3 \mathrm{~mm})$ (one-way ANOVA, $F=1.092$, df $=1, P=0.304$ ). This indicates that restricted growth in fouled mussels was actually due to barnacle epibionts.

Growth of mussels with living barnacle overgrowth was $3.0 \pm 1.6 \mathrm{~mm}$ and did not in the low intertidal significantly differ from mussels with glued barnacle epibionts $(3.4 \pm 1.0 \mathrm{~mm})$ (one-way ANOVA, $F=0.659$, df $=1, P=0.424)$. Therefore, competition for food between mussels and balanids was not responsible for the decreased growth in barnacleovergrown M. edulis.

\section{Discussion}

The results of this study indicate that the growth rate of M. edulis in the Wadden Sea is dominated by tidal level, i.e. it substantially increases with time of submergence. The length increment of $M$. edulis placed subtidally was approximately three times higher than in the intertidal zone. Furthermore, mussel cohort lengths increased from intertidal to subtidal sites. A reduction in mussel growth rate with decreasing submergence time was also found at many other tidal coasts. The availability of food is controlled by immersion time, which in turn is a direct function of tidal height (Baird and Drinnan, 1957; Baird, 1966; Seed, 1968; Suchanek, 1978; Bertness and Grosholz, 1985). Therefore, the longer time for feeding is considered to be the main reason for faster growth in the subtidal. However, an average duration of low intertidal emergence $\left(2 \mathrm{~h} \mathrm{day}^{-1}\right)$ decreased feeding time by about $10 \%$ but lowered growth by about $70 \%$ in this investigation. Thus, additional costs of intertidal life have to be considered. Widdows and Shick (1985) showed that M. edulis is largely anaerobic during tidal exposure when large fluctuations in temperature, salinity and oxygen availability can induce a switch from an aerobic to an anaerobic type of energy metabolism (De Zwaan and Wijsman, 1976; De Zwaan, 1977). During anaerobiosis there is an almost complete reduction in the rates of energetic processes such as digestion and growth (De Zwaan and Mathieu, 1992). The ATP turnover is less than $4 \%$ of the resting aerobic rates (Widdows, 1987). In addition, the restoration of normal physiological functioning following anaerobiosis may be a further component of the aerial exposure costs (De Zwaan and Mathieu, 1992). Interestingly, Gillmor (1982) recorded little difference in growth rates between 0 and $20 \%$ air exposed mussels, and then a marked decline above $20 \%$. However, this was tissue growth rather than shell length. Thus, subtidal mussels generally appear to grow rapidly due to the increase in shell length, but this may not be matched by the tissue growth. Consequently, the tissue growth may show less of a difference than the shell (Widdows, pers. comm., 2000). Eventually, further demands may occur in summer when high temperatures may reduce growth in M. edulis (Almada-Villela et al., 1982) and even cause mortality from heat stress (Tsuchiya, 1983). This might also explain the higher mortality in the intertidal zone as found in this study.

At our study site the density of intertidal M. edulis was two times higher than subtidally, which may result from higher recruitment in the intertidal and and a stronger predation pressure by large crabs (Carcinus maenas L.), ducks (Somateria mollissima L.) and starfish (Asterias rubens L.) in the subtidal zone. Consequently, intraspecific competition for food may have been an additional reason for restricted intertidal mussel growth as suggested by Bertness and Grosholz (1985), Okamura (1986) and Newell (1990). However, comparisons of single and grouped $M$. edulis revealed no influence of mussel density on growth at our study site (Saier and Buschbaum, in prep.). Furthermore, no size and density differences were recorded between intertidal M. edulis located at the edges and the central part of the selected mussel bed (Buschbaum, unpubl. report). Thus, competition for food between mussels is negligible in our comparison of the low intertidal and subtidal zone.

Within intertidal and subtidal mussel beds the genetic composition may vary, with certain strains showing an improved growth rate in specific 
environments. However, cross-transplantation experiments revealed no differences in growth between intertidal and subtidal $M$. edulis placed in either intertidal or subtidal zones. This indicates that the bivalves acclimatised fast to their new environment and suggests that shell length differences of both intertidal and subtidal M. edulis were determined by environmental rather than genotypic factors. Similar conclusions were reached by Coe (1946), Widdows et al. (1984) and Kautsky et al. (1990). In our experiment we used intertidal and subtidal specimens of the same size (25-35 mm shell length) but possibly of different age. Baird (1966) and Bertness and Grosholz (1985) showed that length increment in M. edulis decreased with increasing mussel age. We therefore expected restricted growth of mussels collected in the intertidal zone. However, identical growth rates in intertidal and subtidal mussels transplanted to one particular tidal zone indicate that the growth capacity of the chosen intertidal mussels was not influenced. The age of $M$. edulis seems difficult to determine in relation to mussel size. According to Dankers and Zuidema (1995) small mussels $(<40 \mathrm{~mm})$ grow at almost the same rate in intertidal and subtidal areas and in growth rate comparisons initial lengths of $M$. edulis seem to be of major concern. We found that 1-year-old mussels (1997 cohort) had the same growth rates in mid and low intertidal and subtidal mussel beds, but in their second year (1996 cohort) growth in M. edulis was reduced with increasing emergence time. Thus, tidal emergence predominantly affects 2-year-old mussels and probably also older ones.

Furthermore, our study showed that barnacle epigrowth significantly reduced growth in M. edulis. This finding disagrees with the results of Laihonen and Fuhrman (1986) in the Baltic Sea, where the influence of a single barnacle per mussel was investigated. Decreased growth rates in overgrown mussels possibly be attributed to the following factors: Since both M. edulis and balanids are suspension feeders, competition for food may have occurred. However, in our experiments mussels with glued barnacles showed no difference in growth compared to mussels overgrown with living balanids. Thus, food competition cannot explain the decreased growth in overgrown mussels. Possibly, the structure of barnacle cones might change hydrodynamic conditions and lead to differences in micro- currents. Reduced growth rates were also found in Mytilus californianus (Conrad) overgrown by red algae (Dittmann and Robles, 1991). Such epiphytes may screen out food particles and create a stagnant boundary layer of water from which food is readily depleated (Vogel, 1981; Paine and Suchanek, 1983). Whether such an effect applies to barnacle overgrowth remains obscure. At our study site another important epibiont on intertidal mussel beds is the brown alga Fucus vesiculosus forma mytili (Nienburg) (Albrecht, 1998). These algae negatively affected survival of mussels but effects on growth have not yet been investigated (Albrecht and Reise, 1994). Witman and Suchanek (1984) showed that mussels overgrown with algae are more strongly attached to the substratum to prevent dislodgement due to higher flow forces. Because of this hydrodynamic stress, mussels with epibionts need to invest much energy in byssus thread production (Price, 1983; Okamura, 1986). Such a drag-induced tradeoff effect by epibionts in conjunction with reduced growth was also reported from other epibenthic molluscs such as the periwinkle Littorina littorea (L.) (Wahl, 1996; 1997) and may also apply to the $M$. edulis-S. balanoides association.

We conclude that growth in M. edulis is substantially affected by submergence time and to a lesser extent by barnacle epibionts. However, it has to be taken into consideration that interannual fluctuations in abundance and distribution of barnacles (Southward, 1991; Bertness et al., 1992; Miron et al., 1995) may lead to highly variable growth patterns in M. edulis. In 1998, barnacle cover was heavy on mussels at our low intertidal sites, which harbour most of the M. edulis population (Reise et al., 1994). In such a case, barnacle epibionts may affect the entire M. edulis population of an area by limiting growth, increasing mortality and potentially restricting reproductive output as suggested by Dittman and Robles (1991).

\section{Acknowledgements}

We are most grateful to Werner Armonies for inspiring discussions and thank Karsten Reise for helpful comments and for critically reading the manuscript. We are also grateful to Christian Hennig 
(University of Hamburg, Germany) for statistical advice and two anonymous reviewers for their valuable comments.

This article is dedicated to Jupp Borger in joyful remembrance of his assistance and generous help. This article is in part based on two doctoral studies of C. Buschbaum and B. Saier in the Faculty of Biology, University of Hamburg.

\section{References}

Albrecht, A.S., 1998. Soft bottom versus hard rock: community ecology of macroalgae on intertidal mussel beds in the Wadden Sea. J. Exp. Mar. Biol. Ecol. 229, 85-109.

Albrecht, A.S., Reise, K., 1994. Effects of Fucus vesiculosus covering intertidal mussel beds in the Wadden Sea. Helgoländer Meeresunters. 48, 243-256.

Almada-Villela, P.C., Davenport, J., Gruffydd, L.L.D., 1982. The effects of temperature on the shell growth of young Mytilus edulis L. J. Exp. Mar. Biol. Ecol. 59, 275-288.

Austen, G., 1994. Hydrodynamics and particulate matter budget of Königshafen, southeastern North Sea. Helgoländer Meeresunters. 48, 183-200.

Austen, I., 1994. The surficial sediments of Königshafen; variations over the past 50 years. Helgoländer Meeresunters. 48, 163-171.

Baird, R.H., 1966. Factors affecting the growth and condition of mussels (Mytilus edulis L.). Fish. Invest. Minist. Agric. Fish Food Lond., Ser. II 25, 1-33.

Baird, R.H., Drinnan, R.E., 1957. The ratio of shell to meat in Mytilus as a function of tidal exposure to air. J. Cons. Perm. Int. Explor. Mer. 22, 326-329.

Barnes, H., 1959. Stomach contents and microfeeding of some common cirripedes. Can. J. Zool. 37, 231-236.

Bayerl, K.A., Higelke, B., 1994. The development of northern Sylt during the last Holocene. Helgoländer Meeresunters. 48, 145171.

Bayne, B.L., Worrall, C.M., 1980. Growth and production of mussel Mytilus edulis from two populations. Mar. Ecol. Prog. Ser. 3, 317-328.

Behrens, A., Gayer, G., Günther, H., 1996. Atlas der Strömungen und Wasserstände in der Sylt-Rømø-Bucht. GKSS Forschungszentrum, Geesthacht, Band, 1-8.

Bertness, M.D., Grosholz, E., 1985. Population dynamics of the ribbed mussel Geukensia demissa: the costs and benefits of an aggregated distribution. Oecologia 67, 192-204.

Bertness, M.D., Gaines, S.D., Sephens, E.G., Yund, P.O., 1992. Components of recruitment in populations of the acorn barnacle Semibalanus balanoides (Linnaeus). J. Exp. Mar. Biol. Ecol. 156, 199-215.

Buhs, F., Reise, K., 1997. Epibenthic fauna dredged from tidal channels in the Wadden Sea of Schleswig-Holstein: spatial patterns and a long-term decline. Helgoländer Meeresunters. 51, 343-359.

Buschbaum, C., 2000. Direct and indirect effects of Littorina littorea (L.) on barnacles growing on mussel beds in the Wadden Sea. Hydrobiologia (in press).

Coe, W.R., 1946. A resurgent population of the Californian bay mussel Mytilus edulis diegensis. J. Exp. Zool. 99, 1-14.

Coulthard, H.S., 1929. Growth of the sea mussel. Contr. Canadian. Biol., N S 4, 121-136.

Dankers, N., Zuidema, D.R., 1995. The role of the mussel (Mytilus edulis L.) and mussel culture in the Dutch Wadden Sea. Estuaries 18 (1a), 71-80.

De Zwaan, A., 1977. Anaerobic energy metabolism in bivalve molluscs. Oceanogr. Mar. Biol. Ann. Rev. 115, 103-187.

De Zwaan, A., Mathieu, M., 1992. Cellular biochemistry and endocrinology. In: Gosling, E. (Ed.), The Mussel Mytilus: Ecology, Physiology, Genetics and Culture. Elsevier, Amsterdam, pp. 223-307.

De Zwaan, A., Wijsman, T.C.M., 1976. Anaerobic metabolism in Bivalvia (Mollusca). Characteristics of anaerobic metabolism. Comp. Biochem. Physiol. 54B, 313-324.

Dittmann, D., Robles, C., 1991. Effect of algal epiphytes on the mussel Mytilus californianus. Ecology 72, 286-296.

Faldborg, K., Jensen, K.T., Maagaard, L., 1994. Dynamics, growth, secondary production and elimination by waterfowl of an intertidal population of Mytilus edulis L. Ophelia Suppl. 6, 187-200.

Fréchette, M., Bourget, E., 1985a. Energy flow between the pelagic and benthic zones: factors controlling particulate organic matter available to an intertidal mussel bed. Can. J. Fish. Aquat. Sci. $42,1158-1165$.

Fréchette, M., Bourget, E., 1985b. Food-limited growth of Mytilus edulis L. in relation to the benthic boundary layer. Can. J. Fish. Aquat. Sci. 42, 1166-1170.

Gillmor, R.B., 1982. Assessment of intertidal growth and capacity adaptations in suspension-feeding bivalves. Mar. Biol. 68, 277286.

Harger, J.R.E., 1970. The effect of wave impact on some aspects of the biology of sea mussels. Veliger 12, 401-414.

Howell, D.C., 1997. Statistical Methods for Psychology. 4th ed. Duxbury Press, Belmont. California.

Incze, L.S., Lutz, R.A., Watling, L., 1980. Relationships between effects of environmental temperature and seston on growth and mortality of Mytilus edulis in a temperate northern estuary. Mar. Biol. 57, 147-156.

Kaufmann, K.W., 1981. Fitting and using growth curves. Oecologia 49, 293-299.

Kautsky, N., 1982. Growth and size structure in a Baltic Mytilus edulis population. Mar. Biol. 68, 117-133.

Kautsky, N., Johannesson, K., Tedengren, M., 1990. Genotypic and phenotypic differences between Baltic and North Sea populations of Mytilus edulis evaluated through reciprocal transplantations. I. Growth and morphology. Mar. Ecol. Prog. Ser. 59, $203-$ 210.

Kennedy, V.S., 1976. Desiccation, higher temperatures and upper intertidal limits of three species of sea mussels (Mollusca: Bivalvia) in New Zealand. Mar. Biol. 35, 127-137.

Laihonen, P., Fuhrman, E.R., 1986. The site of settlement indicates commensalism between bluemussel and its epibiont. Oecologia $71,38-40$.

McGrorty, S., 1997. Winter growth of mussels Mytilus edulis 
as a possible counter to food depletion by oystercatchers Haematopus ostralegus. Mar. Ecol. Prog. Ser. 153, 153-165.

McGrorty, S., Goss-Custard, J.D., Clarke, R.T., 1993. Mussel Mytilus edulis (Mytilacea) dynamics in relation to environmental gradients and intraspecific interactions. Neth. J. Aq. Ecol. 27, 163-171.

Miron, G., Boudreau, B., Bourget, E., 1995. Use of larval supply in benthic ecology: testing correlations between larval supply and larval settlement. Mar. Ecol. Prog. Ser. 124, 301-305.

Møhlenberg, F., Riisgard, H.U., 1977. Efficiency of particle retention in thirteen species of suspension feeding bivalves. Ophelia 17, 239-246.

Newell, C.R., 1990. The effects of mussel (Mytilus edulis, Linnaeus, 1758) position in seeded bottom patches on growth at subtidal lease sites in Maine. J. Shellfish Res. 9, 113-118.

Okamura, B., 1986. Group living and the effects of spatial position in aggregations of Mytilus edulis. Oecologia 69, 341-347.

Paine, R.T., Suchanek, T.H., 1983. Convergence of ecological processes between independently evolved competitive dominants: a tunicate-mussel comparison. Evolution 37, 821-831.

Price, H.A., 1983. Structure and formation of the byssus complex in Mytilus (Mollusca Bivalvia). J. Moll. Stud. 49, 9-17.

Reise, K., 1985. Tidal Flat Ecology. Springer, Berlin.

Reise, K., Herre, E., Sturm, M., 1994. Biomass and abundance of macrofauna in intertidal sediments of Königshafen in the northern Wadden Sea. Helgoländer Meeresunters. 48, 201-215.

Seed, R., 1968. Factors influencing shell shape in the mussel Mytilus edulis. J. Mar. Biol. Ass. UK 48, 561-584.

Seed, R., Suchanek, T.H., 1992. Population and community ecology of Mytilus. In: Gosling, E. (Ed.), The Mussel Mytilus: Ecology, Physiology, Genetics and Culture. Elsevier, Amsterdam, pp. 87-169.

Southward, A.J., 1991. 40 years of changes in species composition and population-density of barnacles on a rocky shore near Plymouth. J. Mar. Biol. Ass. UK 71, 495-513.
Suchanek, T.H., 1978. The ecology of Mytilus edulis L. in exposed rocky intertidal communities. J. Exp. Mar. Biol. Ecol. 31, 105120.

Theisen, B.F., 1972. Shell cleaning and deposit feeding in Mytilus edulis L. (Bivalvia). Ophelia 10, 49-55.

Tsuchiya, M., 1983. Mass mortality in a population of the mussel Mytilus edulis L. caused by high temperature on rocky shores. J. Exp. Mar. Biol. Ecol. 66, 101-111.

Vogel, S., 1981. Life in Moving Fluids. Princeton University Press, Princeton.

Wahl, M., 1996. Fouled snails in flow: potential of epibionts on Littorina littorea to increase drag and reduce snail growth rates. Mar. Ecol. Prog. Ser. 138, 157-168.

Wahl, M., 1997. Increased drag reduces growth of snails: comparison of flume and in situ experiments. Mar. Ecol. Prog. Ser. 151, 291-293.

Widdows, J., 1987. Application of calorimetric methods in ecological studies in ecological studies. In: James, A.M. (Ed.), Thermal and Energetic Studies of Cellular Biological Systems. Wright, Bristol, pp. 182-215.

Widdows, J., Shick, J.M., 1985. Physiological responses of Mytilus edulis and Cardium edule to aerial exposure. Mar. Biol. 85, 217-232.

Widdows, J., Donkin, P., Salked, P.N., Cleary, J.J., Lowe, D.M., Evans, S.V., Thomson, P.E., 1984. Relative importance of environmental factors in determining physiological differences between two populations of mussels (Mytilus edulis). Mar. Ecol. Prog. Ser. 17, 33-47.

Wildish, D.J., Kristmanson, D.D., 1985. Control of suspension feeding bivalve production by current speed. Helgoländer Meeresunters. 39, 237-243.

Witman, J.D., Suchanek, T.H., 1984. Mussels in flow-drag and dislodgement by epizoans. Mar. Ecol. Prog. Ser. 16, 259-268. 